\title{
FUNGICIDAL ACTIVITY OF GARLIC (Allium sativum) BULBS EXTRACTS AGAINST PLANTS PATHOGENIC FUNGI
}

\author{
Khairan $^{1,2}$ Aulina $^{3}$, Muhammad Bahi ${ }^{3}$, Cut Nova Eriana ${ }^{3}$, \& Rina Sriwati ${ }^{4}$ \\ ${ }^{1}$ Department of Pharmacy, Faculty of MIPA, University Syiah Kuala, Indonesia \\ Jl. Syech Abdul Rauf No.10 Training Center Unsyiah Darussalam Banda Aceh 23111 \\ ${ }^{2}$ Herbal Medicine Research Center, University Syiah Kuala, Indonesia \\ Jl. Syech Abdul Rauf Training Center Unsyiah Darussalam Banda Aceh 23111 \\ ${ }^{3}$ Department of Chemistry, Faculty of MIPA, University Syiah Kuala, Indonesia \\ Jl. Tgk. Syech Abdurrauf No.3 Darussalam Kopelma Darussalam Syiah Kuala Banda Aceh 23111 \\ ${ }^{4}$ Department of Plant Protection, Faculty of Agriculture, University Syiah Kuala, Indonesia \\ Jl. Tgk. Hasan Krueng Kalee No. 3 Kopelma Darussalam, Kota Banda Aceh 23111 \\ E-mail: khairankhairan@unsyiah.ac.id
}

\begin{abstract}
Fungicidal activity of garlic (Allium sativum) Bulbs extracts against plants pathogenic fungi. Garlic (Allium sativum Linn.) has been known containing organosulphur compounds. These compounds are convinced to possess antibacterial, antifungal, and anticancer activities. The aim of this study was to determine fungicidal activity of garlic bulb extracts against some plants phatogenic fungi. The paper disc agar difussion technique was used to determine fungicidal activity of garlic bulbs extracts. The results showed that in general garlic bulbs extracts provides fungicidal activities. Calculated $\mathrm{EC}_{50}$ values indicated that ethyl acetate garlic bulbs extract was most active against Colletotrichum capsici, Fusarium oxysporum f. sp.capsici, and Sclerotium rolfsii by $\mathrm{EC}_{50}$ values of 48,6; 50,3; and 51.3\% respectively. Meanwhile methanolic garlic bulbs extract was the most active against $S$. rolfsii with $\mathrm{EC}_{50}$ values of $24,3 \%$.
\end{abstract}

Key words: Allium sativum, Colletotrichum capsici, Fusarium oxysporum f. sp. capsici, phyto-fungicide, plants phatogenic fungi, Sclerotium rolfsii

\section{INTRODUCTION}

Chili (Capsicum annuum L.) is one of vegetable commodity cultivated in Indonesia due to its high economic value (Kardinan, 2002). The Directorate General of Horticulture Indonesia mentioned that in 2017, the productivity of $C$. annuum reached 8.4 tons per $\mathrm{Ha}$, this is not much higher than the productivity of chili in 2013 which reached 8.16 tons per Ha (Direktorat Jenderal Hortikultura, 2013; 2017). The problem is caused by pests and diseases (Bosland \& Votana, 2012). The common pests attacking on the chili plants are mostly caused by Colletotrichum capsici (Al-Askar, 2012; Alwathnani \& Perveen, 2012), Fusarium oxysporum f. sp. capsici (Shafique et al., 2015), and Sclerotium rolfsii (Abdel-Fattah et al., 2011). Anthracnose plant disease on chili mostly caused by the fungus $C$. capsici, while wilt and necrosis disease on chili plant usually are caused by the fungus $F$. oxysporum f. sp. capsici. Anthracnose disease in chili causes decreased production of almost $60 \%$ (Duriat et al., 2007; Setiyawati et al., 2007). According to Semangun (2007), the early symptoms caused by the fungus $F$. oxysporum is the leaf become pale mainly on the top of leaf, followed duck down of the stem, and eventually the plants becomes whiter. Abdullah et al. (2015) mentioned that $S$. rolfsii damping-off disease caused loss of almost $80 \%$ of seedbed of chili plants, and when an environmental conditions suitable for the development of this disease, the loss could reach $100 \%$.

Due to high economic values of chili, the farmers tend to use synthetic or commercial pesticides in efforts to control of pests and diseases such as phenylamide and metalaxyl (Basuki, 1988; Bi, 2018). The excessive use of synthetic fungicides and uncontrolled can cause health problems, environmental pollution, kill non-target organisms and resistant to fungicides (Prapagdee et al., 2008; Untung, 1996). To avoid this situation, the use of biofungicide is very potential to develop due to ecofriendly, environmentally safe, and does not cause phytotoxicity (Sigee, 1993; Boonsang et al., 2014). Some extracts from the plant are reported effectively used as biofungicide, such as essential oils of Rutaceae, Eucalyptus globulus and Thymus vulgaris are known to effectively inhibit the growth of fungi Pythium spp., Rhizoctonia solani (Katooli et al., 2011) and Colletotrichum gloeosporioides (Hur et al., 2000). Nosrati et al. (2011) reported that the essential oil of 
Mentha spicata can be used to control the fungus $F$. oxysporum f. sp. radicis-cucumerinum on cucumber. Pawar \& Thaker (2007) also reported that the essential oil of citronella, clove, cinnamon bark and leaves have fungicidal activity against Alternaria porri and Fusarium oxysporum f. sp. Cicer. Rhizoctonia solani (Katooli et al., 2011) and Colletotrichum gloeosporioides (Hur et al., 2000).

Aqueous garlic extract is reported to have activity against Botrytis cinerea, Penicillum expansum, and Neofabraea alba. Some garlic extracts have been also reported to have antifungal effect on the fungus Fusarium oxysporum f. sp. phaseoli and Penicillium digitatum (Obagwu \& Korsten, 2003). Antimicrobial activity of garlic is apparently due to the high content of organosulfur compounds (Khadri et al., 2011; Ankri \& Mirelman, 1999) such as allycin or diallyl thiosulfinate (Block, 2010), allyl ethyl trisulfides, dithiins, ajoen, diallyl sulfides, diallyl disulfides, allyl propyl disulfides, diallyl trisulfides, and diallyl tetrasulfides (Amagase, 2006; Chekki et al., 2016). The purpose of this study was to determine the fungicidal activity of some garlic extracts on plant pathogenic fungi such as C. capsici, F. capsici, and $S$. rolfsii.

\section{MATERIALS AND METHODS}

Research Site. The research was conducted at the Laboratory of Plant Diseases, Department of Plant Diseases, Faculty of Agriculture, University of Syiah Kuala from January 2018 to June 2018.

Preparation of Simplicial Garlic Bulb. Garlic bulbs used in this study was obtained from the traditional market of Lambaro, Aceh Besar District. Criteria samples taken are garlic bulbs with cloves of $\pm 2 \mathrm{~cm}$ size. Garlic bulb were hand-cut and then exhaustively dried at room temperature $\left(25-29^{\circ} \mathrm{C}\right)$ for 4 weeks to produce a simplicial of garlic bulb. This simplicia was then used for the preparation of extracts of garlic bulbs extracts.

Preparation of Garlic Bulb Extracts. Preparation of garlic bulb extracts were performed according to the method developed by Anief (2010) with slight modification. A $500 \mathrm{~g}$ of simplicial garlic bulb were macerated with $3 \mathrm{~L}$ of $n$-hexane at room temperature for 7 days with occasionally shake, and the macerate of $n$-hexane than filtered. The residue was macerated again with $2 \mathrm{~L}$ of $n$-hexane for next 3 days and filtered. The macerates were than combined and evaporated in vacuo to afford a crude extract of $n$-hexane. Using the same procedure, the total garlic residue of $n$-hexane was extracted respectively with cyclohexane, ethyl acetate, and methanol to obtain the extracts of cyclohexane, ethyl acetate, and methanol.

Phytochemicals Screening of Garlic Extracts. The methods described by Harborne (1980) were used for the phytochemicals analysis. The phytochemicals tests of garlic extracts in this study included alkaloids, flavonoids, saponins, and tannins.

Fungicidal Activity. The antifungal activity of garlic extracts was conducted by a disc diffusion (KirbyBauer) method. Potato dextrose agar (PDA) was poured into sterile petri dishes and allowed to solidify. The isolates of $C$. capsici, F. oxysporum, and S. rolfsii in separate of sterile petri dishes were spread all over the surface of solidified PDA using a sterile cotton bud. The paper disc with a diameter of approximately $6 \mathrm{~mm}$ was placed on the surface of the agar medium. Each disc was filled with $20 \mathrm{ml}$ of garlic extracts with the concentration of $10,25,50,75$, and $100 \%$. In this assay, a paper disc of nystatin was used as a positive control. The plates were incubated at $37^{\circ} \mathrm{C}$ for 48 hours, and the diameter of inhibition zones surrounding the agar disc was measured in millimeter using a ruler (WHO, 2009).

The $\mathbf{E C}_{50}$ values. The $\mathrm{EC}_{50}$ values were calculated with sigmoidal curve by using the OriginPro 7.5 software using Boltzmann sigmoidal curve.

\section{RESULTS AND DISCUSSION}

Phytochemical Screening. The phytochemicals screening of garlic extracts is presented in Table 1. It shows the results of the preliminary phytochemicals analysis. The results showed that alkaloids were present in all of garlic extracts used in this study. These results are consistent with studies that have been conducted by Safithri (2004), Rustama (2005), Sovia et al., (2011), and Divya et al., (2017) which stated that an extract of $n$-hexane, ethyl acetate, and methanol garlic contains alkaloids. Meriga et al., (2012), also mentions that the $n$-hexane extract of garlic bulbs contain alkaloids. According to Sadikin (2002), garlic is a Liliaceae plant and rich of alkaloid content. Alkaloids are semi-polar compounds which soluble in semi-polar and polar solvents (Harborne, 1987), and non-polar solvent (Baht et al., 2006).

Table 1 also reveals that the ethyl acetate and methanolic garlic extracts containing the metabolite of 
saponins. These results are consistent with studies that have been conducted by Sovia et al., (2011) and Lanzotti et al. (2012) which mentioned that ethyl acetate and methanol garlic extracts are positive containing of saponins. Shah \& Seth (2010), also stated that garlic contains metabolites alkaloids and saponins. According to Gholkar et al. (2013), a compound that plays a role in the antioxidant activity of garlic are phenolic compounds, steroids, alkaloids and saponins.

Fungicidal Activity. The fungicidal activity of garlic extracts ( $n$-hexane, cyclohexane, ethyl acetate, and methanol garlic extracts) against plant pathogenic fungi C. capsici, F. oxysporum, and $S$. rolfsii obtained is presented in Table 2. The result showed that the fungicidal activities of garlic extracts were appeared at concentration above of $20 \%$. Table 2 shows that the diameter inhibition zone of $n$-hexane garlic extract (HGE) on plant pathogenic fungi ranged between 14$24 \mathrm{~mm}$, with the highest inhibition on C. capsici and $S$. rolfsii. Meanwhile, the highest fungicidal activity of cyclohexane garlic extract (CGE) against plant pathogenic fungi was on $S$. rolfsii at concentration of $50 \%$. The results also mentioned that ethyl acetate garlic extract (EAGE) has a strongest activity against all plant pathogenic fungi at all concentrations tested with ranged of diameter inhibition zone between 27-46 mm.

HGE (hexane garlic extract); CGE (cyclohexane garlic extract); EAGE (ethyl acetate garlic extract); and MGE (methanolic garlic extract); $\left(\mathrm{C}^{+}\right)$control positive; $C$. capsici); F. oxysporum and $S$. rolfsii). The diameters inhibition zone were determined in triplicate. Methanol garlic extract (MGE) has higher fungicidal activity against Sclerotium rolfsii and Fusarium oxysporum f. sp.capsici with a diameter of inhibition zone ranged from 10-30 $\mathrm{mm}$ (Table 2).

Interestingly, the results presented that the higher concentration of garlic extracts have lower fungicidal activity. This is presumably due to lower solubility with the result that the distribution of active metabolite from garlic extract to the cell membrane of fungi is limited so that the antifungal activity becomes low.

According to Morales et al. (2003) the antifungal activity of plant or material extract can be determined by diameters of inhibition zone (Table 3 ).

The antifungal activity of garlic extracts (HGE, CGE, EAGE, and MGE) are expected due to organosulfur compounds and active metabolite such as alkaloids and saponins contained in garlic extracts. The phytochemicals screening results presented in Table 1 indicate that all garlic extracts positively contain alkaloid. Aniszewki (2007) and Amagase et al. (2001) reported that the mechanisms of alkaloids on fungi with inhibiting the process of cell respiration. Tariq et al. (1988), stated that allycin (diallyl-dithiosulfinate) is the class of alkaloids contained in garlic very important role in the activity of garlic. Allycin is organosulfur compounds that believed have antifungal activity (Lawson et al., 1991).

The results also show that ethyl acetate and methanol garlic extracts have stronger fungicidal activity against all plant pathogenic fungi compared with $n$ hexane and cyclohexane garlic extracts. These activities were due to contains secondary metabolite of saponins. Saponins, are non-organosulfur compound which have hydrophilic glycoside group (Tariq et al., 1988). This compound is believed to have properties as antibacterial, antimicrobial, and antiinflamantori (Harmatha, 2000). According to Cowan (1999) and Nuria (2009), saponins are polar compounds that can attract water molecules and dissolve of lipids. Thereby these compounds can destabilizing the membrane of fungi cells by decreased of surface tension of the cell membrane in the results that lysis of the cell, and eventually caused death cells. Saponins that contained in garlic is saponins in the group of erubocide-B. This group of saponins is plays very important role in antifungal activity of garlic (Tariq et al., 1988), acts as antifungal activity against several plant pathogenic fungi (Morrissey \& Osburn, 1999) antibacterial and antifungal activity (Turk, 2006). According to Obagwu \& Korsten (2003), the

Table 1. Phytochemicals profile of garlic extracts (Allium sativum)

\begin{tabular}{lcccc}
\hline & \multicolumn{4}{c}{ Phytochemical constituents } \\
\cline { 2 - 5 } Secondary metabolites & HGE & CGE & EAGE & MGE \\
\hline Alkaloids & + & + & + & + \\
Flavonoids & - & - & - & - \\
Saponins & - & - & + & + \\
Tannins & - & - & - & - \\
\hline
\end{tabular}

HGE (hexane garlic extract); CGE (cyclohexane garlic extract); EAGE (ethyl acetate garlic extract); and MGE (methanolic garlic extract); (+) present; (-) absent. 
mechanism action of saponins is by forming a complex reaction with the cell membrane sterols in fungi. These complex reactions caused the porosity of fungal cell membrane and consequently fungal cell membrane integrity over time damage. In this study, we used nystatin as a positive control. Nystatin (also called micostatin), is an antifungal from the class of polyene (Macesic \& Wingard, 2018). The mechanism action of nystatin as antifungal is by destroying the fungal cell wall to form a channel, so that the cells lose electrolyte or ion channels such as $\mathrm{K}^{+}$ions. These conditions causes the gradient proton inside the cell is disturbing, and eventually causes death cell (Bhanderi et al., 2009). Several researchers reported that besides sterols, ergosterols is also as main target of nystatin as antifungal so that this compound is often used as a positive control for antifungal (Ridawati et al., 2011).

Table 2. The fungicidal activity of garlic extracts against plant pathogenic fungi

\begin{tabular}{|c|c|c|c|c|}
\hline \multirow{3}{*}{ Extract } & \multirow{3}{*}{ Concentration $(\%)$} & \multicolumn{3}{|c|}{ Diameters of inhibition zone (mm) } \\
\hline & & \multicolumn{3}{|c|}{ Plant pathogenic fungi } \\
\hline & & C. capsici & F. oxysporum & S. rolfsii \\
\hline \multirow[t]{6}{*}{ HGE } & $\mathrm{C}^{+}$ & 24.0 & 23.0 & 9.0 \\
\hline & 10 & 0 & 0 & 0 \\
\hline & 25 & 20.0 & 19.5 & 15.5 \\
\hline & 50 & 24.0 & 20.5 & 24.0 \\
\hline & 75 & 27.0 & 19.6 & 15.3 \\
\hline & 100 & 19.0 & 14.7 & 15.0 \\
\hline \multirow[t]{6}{*}{ CGE } & $\mathrm{C}^{+}$ & 24.0 & 23.0 & 9.0 \\
\hline & 10 & 0 & 0 & 0 \\
\hline & 25 & 32.0 & 19.3 & 21.5 \\
\hline & 50 & 30.5 & 23.0 & 38.0 \\
\hline & 75 & 27.0 & 27.0 & 21.0 \\
\hline & 100 & 28.0 & 28.5 & 20.0 \\
\hline \multirow[t]{6}{*}{ EAGE } & $\mathrm{C}^{+}$ & 24.0 & 23.0 & 9.0 \\
\hline & 10 & 0 & 0 & 0 \\
\hline & 25 & 27.0 & 20.7 & 22.2 \\
\hline & 50 & 39.0 & 23.3 & 26.5 \\
\hline & 75 & 46.0 & 27.6 & 44.3 \\
\hline & 100 & 42.0 & 27.0 & 33.5 \\
\hline \multirow[t]{6}{*}{ MGE } & $\mathrm{C}^{+}$ & 24.0 & 23.0 & 9.0 \\
\hline & 10 & 0 & 0 & 0 \\
\hline & 25 & 15.0 & 13.0 & 10.0 \\
\hline & 50 & 27.5 & 19.0 & 30.2 \\
\hline & 75 & 20.7 & 19.0 & 21.0 \\
\hline & 100 & 21.6 & 30.3 & 23.0 \\
\hline
\end{tabular}

HGE (hexane garlic extract); CGE (cyclohexane garlic extract); EAGE (ethyl acetate garlic extract); MGE (methanolic garlic extract); $\left(\mathrm{C}^{+}\right)$positive control; The diameters of inhibition zone were determined in triplicate.

Table 3. Determination of antifungal activity by diameters of inhibition zone according to Morales et al. (2003)

\begin{tabular}{cc}
\hline Diameters of inhibition zone $(\mathrm{mm})$ & Antifungal activity \\
\hline$<6$ & No active \\
$6-10$ & Less active \\
$10-20$ & Active \\
$>20$ & Strong active \\
\hline
\end{tabular}


In addition, table shows that nystatin has lowest activity against $S$. rolfsii with the averages of diameters inhibition zone is $9 \mathrm{~mm}$. Fichtner (2005), states that the fungus $S$. rolfsii has the ability to survive and thrive in a variety of environmental conditions. Haas \& Defago (2005) also stated that the ability of $S$. rolfsii against environmental conditions due to this fungi has higher virulence (degree of pathogenicity) compared with other plant pathogenic fungi.

Due to higher fungicidal activity of ethyl acetate garlic extract (EAGE) compared with other garlic extracts, we isolated the EAGE with column chromatography using chloroform: ethanol: water with a ratio of 6: 4: $1(\mathrm{v} / \mathrm{v})$ as eluent system. The results produced two dominant isolates of EAGE namely isolates $\mathrm{A}$ and $\mathrm{B}$, with the $\mathrm{Rf}$ value of each isolate are 0.8 and 0.6 respectively. To each isolate was then determined the fungicidal activity against plant pathogenic fungi such as $C$. capsici, $F$. oxysporum, and $S$. rolfsii. The fungicidal activity of the isolates is presented in Table 4.

Table 4 shows that the two isolates of the ethyl acetate extract of garlic did not show any fungicidal activity against $C$. capsici, F. oxysporum, and $S$. rolfsii.
These results indicated that the fungicidal activity of EAGE acts synergy between organosulfur compounds and secondary metabolites of alkaloids and saponins in inhibiting of plant pathogenic fungi.

$\mathbf{E C}_{50}$ Value. Half maximal effective concentration $\left(\mathrm{EC}_{50}\right)$ refers to the concentration of a drug, antibody or toxicant that induces a response halfway between the baseline and the maximum after a specified exposure time. The $\mathrm{EC}_{50}$ values of garlic extracts on plant pathogenic fungi obtained by sigmoidal curve at position $\mathrm{x}$ at y 50 using software OriginPro 7.5 software are listed in Table 5 and the sigmoidal curves are presented in Figure 1.

Table 5 shows that overall EAGE have a lower $\mathrm{EC}_{50}$ values compared with HGE, CGE, and MGE. Meanwhile, MGE have a lowest $\mathrm{EC}_{50}$ values on $S$. rolfsii with the $\mathrm{EC}_{50}$ values is $24.3 \%$, this result indicated that EAGE have a higher activity against all plant pathogenic fungi. Additionally, MGE showed strongest fungicidal activity against $S$. rolfsii. Saxena et al. (2013) mentioned that the extract with lower $\mathrm{EC}_{50}$ values indicates a higher activity.

Table 4. The fungicidal activity of isolates A and B against plant pathogenic fungi

\begin{tabular}{cccc}
\hline \multirow{2}{*}{ Isolate } & \multicolumn{3}{c}{ Diameters of inhibition zone $(\mathrm{mm})$} \\
\cline { 2 - 4 } & C.capsici & Plant pathogenic fungi \\
\hline Nystatin $\left(\mathrm{C}^{+}\right)$ & 24.0 & 23.0 & S.rolfsii \\
EAGE $(100 \%)$ & 42.0 & 27.0 & 9.0 \\
Isolate A & 0 & 0 & 33.5 \\
Isolate B & 0 & 0 & 0 \\
\hline
\end{tabular}

EAGE (ethyl acetate garlic extract); $\left(\mathrm{C}^{+}\right)$positive control. The diameters of inhibition zone were determined in triplicate.

Table 5. The EC50 values of garlic extracts against plant pathogenic fungi using OriginPro 7.5 software

\begin{tabular}{cccc}
\hline \multirow{2}{*}{ Extracts } & \multicolumn{3}{c}{ EC $_{50}$ values $(\%)$} \\
\cline { 2 - 4 } & C. capsici & F. oxysporum & S. rolfsii \\
\hline HGE & 75.4 & 92.2 & 79.9 \\
CGE & 50.5 & 55.6 & 73.7 \\
EAGE & 48.6 & 50.3 & 51.3 \\
MGE & 75.6 & 96.0 & 24.3 \\
\hline
\end{tabular}

EAGE (ethyl acetate garlic extract); $\left(\mathrm{C}^{+}\right)$control positive. The diameters inhibition zone were determined in triplicate. 

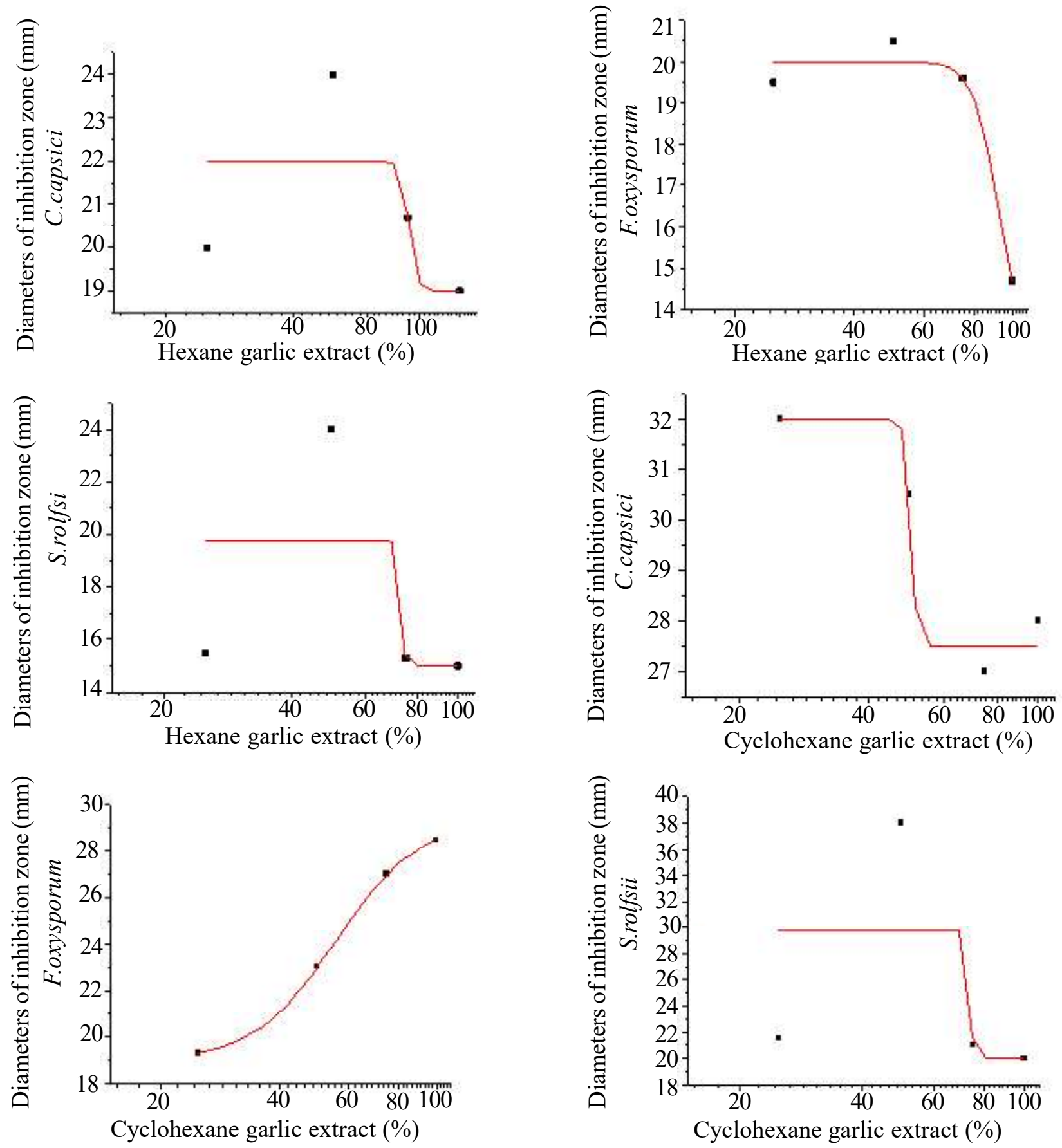

Figure 1. The sigmoidal curve $\mathrm{EC}_{50}$ of garlic extracts on several plant pathogenic fungi. The $\mathrm{EC}_{50}$ values were fitted based on sigmoidal Boltzmann curves-fitting using OriginPro 7.5 software 

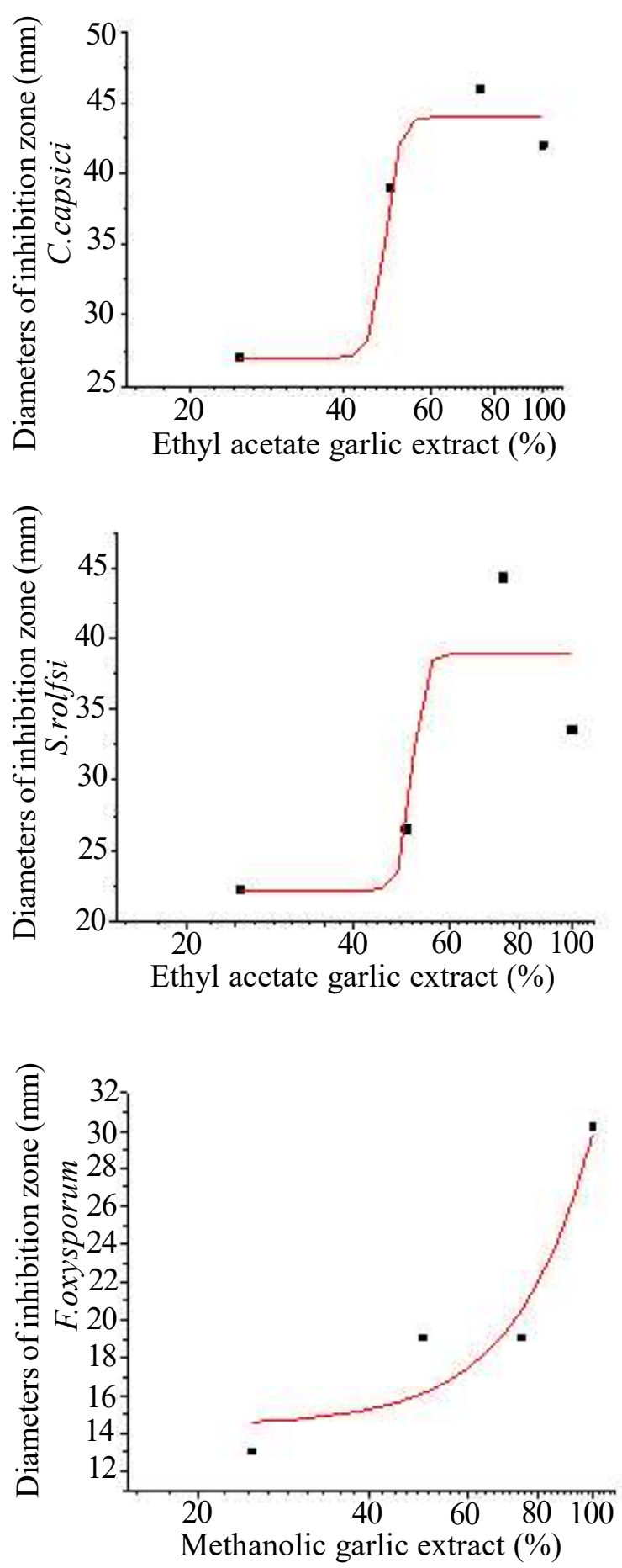
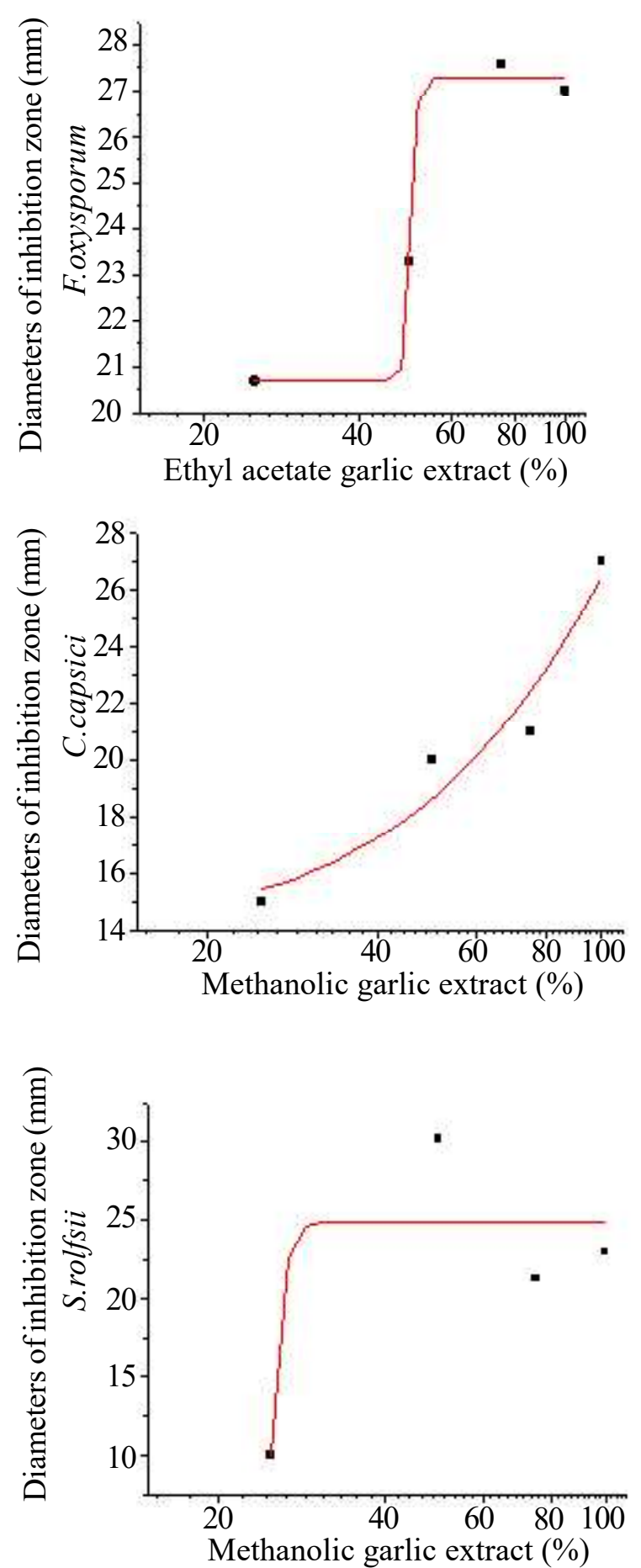

Figure 1. The sigmoidal curve $\mathrm{EC}_{50}$ of garlic extracts on several plant pathogenic fungi. The $\mathrm{EC}_{50}$ values were fitted based on sigmoidal Boltzmann curves-fitting using OriginPro 7.5 software (continued).

\section{CONCLUSION}

Phytochemical screening test showed that the garlic extracts of $n$-hexane, cyclohexane, ethyl acetate, and methanol positively containing alkaloids, while ethyl acetate, and methanol garlic extract also contain saponins.
The ethyl acetate extract of garlic has the highest activity against fungi $C$. capsici, F. oxysporum f. sp. capsici, and $S$. rolfsii, while the methanol extract of garlic has the highest activity against fungi $S$. rolfsii. 


\section{ACKNOWLEDGMENT}

The research was funded by Directorate General of Institutions of Science and Technology and Ministry of Research, Technology and Higher Education through Fundamental research, with BCHP Number: 46/ UN11.2/PP/SP3/2016.

\section{REFERENCES}

Abdel-Fattah GM, El-Haddad SA, Hafez EE, \& Rashad YM. 2011. Induction of defense responses in common bean plants by arbuscular mycorrhizal fungi. Microbiol. Res. 166(4): 268-281.

Abdullah TH, Kandil O, Elkadi A, \& Carter J. 1988. Garlic revisited: therapeutic for the major diseases of our times? J. Natl. Med. Assoc. 80(4): 439445 .

Al-Askar AAA. 2012. In vitro antifungal activity of three Saudi plant extracts against some phytopathogenic fungi. J. Plant Protec. Res. 52(4): 458-462.

Alwathnani HA \& Perveen K. 2012. Biological control of fusarium wilt of tomato by antagonist fungi and cyanobacteria. Afr. J. Biotechnol. 11(5): 11001105.

Amagase H, Petesch BL, Matsuura H, Kusuga S, \& Itakura Y. 2001. Intake of garlic and its bioactive components. J. Nutr. 131(3): 955S-962S.

Amagase H. 2006. Clarifying the real bioactive constituents of garlic. J. Nutr. 136(3): 716S-725S.

Anief M. 2010. Ilmu Meracik Obat: Teori dan Praktik. Gadjah Mada University Press, Yogyakarta.

Aniszewki T. 2007. Alkaloid-Secrets of Life. Elsevier. Amsterdam.

Ankri S \& Mirelman D. 1999. Antimicrobial properties of allicin from garlic. Microbes Infect. 1(2):125129.

Baht SV, Nagasampagi BA, \& Meenakshi S. 2006. Natural Product: Chemistry and Application. Narosa Publishing House. New Delhi India.

Basuki RS. 1988. Analisis biaya dan pendapatan usaha tani cabai merah di Desa Kemurang Kulon, Brebes. Bul. Penel. Hort. 16(2):115-121.

Bhanderi BB, Yadav MM, \& Roy A. 2009. Antifungal drug resistance concerns for veterinarians. Veterinary World. 2(5): 204-207.
Block E. 2010. Garlic and Other Alliums: The Lore and the Science. RSC Publishing. Cambridge. United Kingdom. England.

Boonsang N, Dethoup T, Singburaudom N, Gomes NGM, \& Kijjoa A. 2014. In vitro antifungal activity screening of crude extracts of soil fungi against plant pathogenic fungi. Biopest. 7(2): 156-166.

Bosland PW \& Kotava EJ. 2012. Peppers: Vegetable and Spice Capsicums. Second ed. CAB International. Wallingford, UK.

Chekki R, Najjaa H, Zouari N, Mathe A, \& Bouzouita N. 2016. Detection of organo-sulphur volatiles in Allium sativum by factorial design. Nat. Prod. Chem. Res. 4(2): 1-5.

Cowan MM. 1999. Plant products as antimicrobial agents. Clin. Microbiol. Rev. 12(4): 564-582.

Departemen Kesehatan Republik Indonesia (Depkes). 1995. Farmakope Indonesia. Edisi Ketiga. Depkes RI. Jakarta.

Direktorat Jenderal Hortikultura. 2013. Statistik Produksi Hortikultura Tahun 2013. Kementerian Pertanian. Jakarta.

Direktorat Jenderal Hortikultura. 2017. Statistik Produksi Hortikultura Tahun 2017. Kementerian Pertanian. Jakarta.

Direktorat Jenderal Pengawas Obat dan Makanan (Dirjen POM). 1997. Materia Medika Indonesia. Jilid 6. Direktorat Jenderal Pengawas Obat dan Makanan. Jakarta.

Divya BJ, Suman B, Venkataswamy M, \& Thyagaraju K. 2017. A study on phytochemicals, fungtional groups and mineral composition of Allium sativum (garlic) cloves. Int. J. Curr. Pharm. Res. (9)3: $42-45$.

Duriat AS, Gunaeni N, \& Wulandari AW. 2007. Penyakit Penting pada Tanaman Cabai dan Pengendaliannya. Balai Penelitian Tanaman Sayuran. Bandung.

Fichtner EJ. 2005. Sclerotium rolfsii Sacc. 'Kudzu of the Fungal World'. Soilborne Plant Pathogens. Pathogen Profiles. North Carolina State University.

Golkhar MS, Mulik MB, \& Laddha KS. 2013. Fate of B-asarone in Ayurvedic sodhana process of Vacha. J. Ayurveda Integr. Med. Reid. 4(1):1922. 
Harborne JB. 1987. Metode Fitokimia: Penuntun Cara Modern Menganalisis Tumbuhan. Cetakan Kedua. ITB. Bandung.

Harmatha J. 2000. Chemo-ecological role of spirostanol saponins in the interaction between plant and insects. In: Olezsek W \& Marston A (Eds.). Saponins in food, Feedstuffs and Medicinal Plants. pp. 129-141. Proceedings of the Phythochemical Society of Europe. Springer, Dordrecht. The Netherlands.

Haas D \& Défago G. 2005. Biological control of soilborne pathogens by fluorescent pseudomonads. Nat. Rev. Microbiol. 3: 307-319.

Hur JS, Ahn SY, Koh YJ, \& Lee CI. 2000. Antimicrobial properties of cold-tolerant Eucalyptus species against phytopathogenic fungi and food-borne bacterial pathogens. Plant Path J. 16(5): 286289.

Kanan GJ \& Al-Najar RA. 2008. In vitro antifungal activities of various plant crude extracts and fractions against citrus post-harvest disease agent Penicillium digitatum. Jordan J. Biol. Sci. 1(3): 89-99.

Kardinan A. 2002. Pestisida Nabati: Ramuan dan Aplikasi. Penebar Swadaya. Jakarta.

Katooli N, Maghsodlo R, \& Razavi SE. 2011. Evaluation of eucalyptus essential oil against some plant pathogenic fungi. J. Plant Breed. Crop Sci. 3(2): 41-43.

Khadri S, Boutefnouchet N, \& Dekhil M. 2010. Antibacterial activity evaluation of Allium sativum essential oil compared to different Pseudomonas aeruginosa strains in Eastern Algeria. St. Cerc. St. CICBIA. 11(4): 421-428.

Lanzotti V, Barile E, Antignani V, Bonanomi G, \& Scala F. 2012. Antifungal saponins from bulbs of garlic, Allium sativum L. var. Voghiera. Phytochemistry. 78: 126-134.

Lawson LD, Wood SG, \& Hughes BG. 1991. HPLC analysis of allicin and other thiosulfonates in garlic clove homogenates. Planta Med. 57(3): 263-270.

Macesic N \& Wingard JR. 2018. Nystatin. In: Grayson ML (Ed). Kucers' the Use of Antibiotics: a Clinical Review of Antibacterial, Antifungal, Antiparasitic, and Antiviral Drugs. pp. 144. Seventh Edition. CRC Press. Boca Raton, FL.
Merige B, Mopuri R, Mrali, Krisna T, Meriga B, Mopuri $\mathrm{R}$, \& Muralikrisna. 2012. Insecticidal, antimicrobial and antioxidant activities of bulbs extracts of Allium sativum. Asian Pac. J. Trop. Med. 5(5): 391-395.

Morales G, Sierra P, Mancilla A, Parades A, Loyola LA, Gallardo O, \& Borquez J. 2003. Secondary metabolites from four medical plants from Nothern Chille: Antimicrobial activity and biotoxicity against Artemia salina. J. Chil. Chem. Soc. 48(2): 13-18.

Morrissey JP \& Osbourn AE. 1999. Fungal resistance to plant antibiotics as a mechanism of pathogenesis. Microbiol. Mol. Biol. Rev. 63(3): 708-724.

Nosrati S, Esmaeilzadeh-Hosseini SA, Sarpeleh A, Soflaei-Shahrbabak M, \& Soflaei-Shahrbabak Y. 2011. Antifungal activity of spearmint (Mentha spicata L.) essential oil on Fusarium oxysporum f. sp. radicis-cucumerinum the causal agent of stem and crown rot of greenhouse cucumber in Yazd Iran. ICEAE. 15: 52-56.

Nuria MC, Faizatun A, \& Sumantri. 2009. Uji aktivitas antibakteri ekstrak etanol daun jarak pagar (Jatropha curcas L.) terhadap bakteri Staphylococcus aureus ATCC 25923, Escherechia coli ATCC 25922 dan Salmonella typhi ATCC 1408. MEDIAGRO. 5(2): 26-37.

Obagwu J \& Korsten L. 2003. Control of citrus green and blue moulds with garlic extracts. Euro $J$. Plant Pathol. 109(3): 221-225.

Pawar VC \& Thaker VS. 2007. Evaluation of the anti Fusarium oxysporum f. sp. cicer and antiAlternaria porri effects of some essential oils. World J. Microbiol. Biotech. 23(8): 1099-1106.

Prapagdee B, Akrapikulchart U, \& Mongkolsuk S. 2008. Potential of a soil-borne Streptomyces hygroscopicus for biocontrol of Anthracnose disease caused by 14 Colletotrichum gloeosporioides in orchid. J. Biol. Sci. 8(7): 1187-1192.

Ridawati, Jenie BSL, Djuwita I, \& Sjamsuridzal W. 2011. Aktivitas antifungal minyak atsiri jinten putih terhadap Candida parapsilosis SS25, C. orthopsilosis NN14, C. metapsilosis MP27, dan C. etchelsii MP18. Makara Sains. 15(1): 5862. 
Rustama MM, Rahayuningsih SR, Kusmoro J, \& Safitri R. 2005. Uji aktivitas antibakteri dari ekstrak air etanol bawang putih (Allium sativum L.)terhadap bakteri Gram negatif dan bakteri Gram positif. Biotika. 4(2): 1-8.

Sadikin M. 2002. Biokimia Enzim. Wijaya Medika. Jakarta.

Safithri M. 2004. Aktivitas antibakteri bawang putih (Allium sativum) terhadap bakteri Mastitis subklinis secara in vitro dan in vivo pada tikus putih (Rattus novergicus). Tesis. IPB. Bogor.

Shah B \& Seth AK. 2010. Textbook of Pharmacognosy and Phytochemistry. Reed Elsevier India Private Lomited, New Delhi.

Saxena M, Saxena J, Nema R, Singh D, \& Gupta A. 2013. Phytochemistry of medicinal plants. $J$ Pharmacognosy Phytochemistry. 1(6): 168-82.

Sebaugh JL. 2010. Guidelines for accurate EC50/IC50 estimation. Pharm. Stat. 10(2): 128-134.

Semangun H. 2007. Penyakit-Penyakit Tanaman Hortikultura di Indonesia. Edisi Kedua. Gadjah Mada University Press. Yogyakarta.

Setiyowati H, Surahman M, \& Wiyono S. 2007. Pengaruh seed coating dengan fungisida benomil dan tepung curcuma terhadap patogen antraknosa terbawa benih dan viabilitas benih cabai besar (Capsicum annuum L.). Bul. Agron. 35(3): 176182.

Shafique S, Asif M, \& Shafique S. 2015. Management of Fusarium oxysporum f. sp. capsici by leaf extract of Eucalyptus citriodora. Pak. J. Bot. 47(3): 1177-1182.

Sigee DC. 1993. Bacterial Plant Pathology: Cell and Molecular Aspects. Cambridge University Press. United Kingdom.

Sovia E, Sukandar EY, Sigit JI, \& Sasongko LDN. 2011. Efek rimpang kunyit (Curcuma longa L.) dan bawang putih (Allium sativum L.) terhadap sensitivitas insulin pada tikus galur Wistar. $M K B$. 43(4): 153-159.

Taufiq H, Supriyadi, \& Sarjiyah. 2015. Pengaruh pemberian ekstrak daun sirih (Piper betle L.) untuk mengendalikan damping-off pada tanaman cabai (Capsicum annum). Planta Tropika J. Agro. Science. 3(1): 60-66.

Turk FM. 2006. Saponins versus plant fungal pathogens. J. Cell Mol. Biol. 5: 13-17.

Untung K. 1996. Pengantar Pengelolaan Hama Terpadu. Universitas Gadjah Mada Press. Yogyakarta.

Wang B, Xu S, Cao Y, Liu F, Zhao X, \& Feng. 2018. Fungicidal activity of 10-deacetylbacatin III against Phytophthora capsici via inhibiting lysine biosynthesis. Pestic. Biochem. Phys. 152: 114121.

World Health Organization (WHO). 2009. Monograf on Medical Plant. Genava. Swiss. 